\title{
THE FUNCTION AND DISTRIBUTION OF UKEZUTSUMI OR PROTECTION BANKS IN THE YAMATO BASIN \\ Hideharu UMEZAKI
}

(1) All over the Yamato Basin which has been known as a droughty area are built bulworks, so-called "Ukezutsumi" or Protection Bank. The studies concerning these banks are important to learn about the growth of towns and villages as well as the regional characteristics of Yamato Province. This manuscript shows the result of my field survey about them.

(2) The floods in the Yamato Basin have given damages to all the communities in the basin below the height of 100 meters above the sea-level. Flood protection warehouses and Ukezutsumi Banks are to be seen here and there all over the region, but banks are more frequently found in the low lands where rivers and streams meet together.

(3) The origin of the Banks is presumed to be ancient, but the exact date has not yet been ascertaind. They are disributed along the rivers to protect jointly in case of broken banks of stagnant water.

(4) These banks of accumulated earth are different in their size, shape, and construction acording to their surroundings, and are sharply in contrast with each other between the upper part of a river and the lower part.

(5) The banks are maintained by the strict rules set up by the communities separately or jointly. These rules are indicative of either egoistic or cooperative attitude of the villagers.

(6) After the field survey the following results were discovered :

(a) Both droughts and floods are the characteristics of the Yamato Basin where the control for river waters is insufficient.

(b) In relation to the natural surroundings, a strong community is formed, which, however, results in the stagnation of community.

(c) In order to solve many problems concerning the banks, it is necessary to have a unified and systematic plan of improving the environment all over the basin.

\section{太閤検地の一環としての『長宗我部検地』の村落諭.}

\section{その歴史地理学的考察*}

枟本 僼 泰

\section{1.はしがき}

近世村落構造論，その歴史地理学分野の研究史は

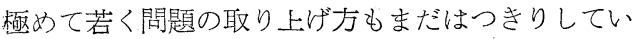
ないというのが現状であろう。したがつて間題提起 的な事例研究の蓄積がまず要請されなくてはならな い段階と思うのであるが，ここで考えたいのは研究 深化を目標としていかなる個別的研究が要求せられ るかといつた点である. 分断的稀少的資料をあれや
これやと集めてみたところで一般性つ把握は資料の 個別性にネグレクトされて，遂には混迷の中に失わ れてしまう晾それがある。結論的にはいるんな条件 を考究するに足る諸資料を可能なるかきりに集めて みることである，多くの関連条件にたえうる資料と 多面的考察法の適用をもつでする個別研究は，やが てはより高次な現象の規定理解をつかみとる端緒を われわれに開現しうるように思われるのである・文

* 枯研究は，1958 年 2 月，德島市における「社会経済史学会」での発表を加筆修正したものである. 
字通り各地の実態を明らかにしなければ普遍的理解 が不可能であるとするならば，たとえば戦国期城下 町とか近世初頭の村落論等の究明は初めから研究断 念を余儀なくされるのではなからうかともあれ事 例的研究も有意的に個別を一般に高めるに足る資料 的前提と解彩の方向が必要となる. 本稿で使用する 根本資料は天正 16 年を中心とする『長宗我部地検 帖』であるが，その斯学研究資料としての特性につ いてはすでに別稿1で論じた通りである. 小論はこ うした資料を䁫使して物部川全流域の近世初頭の郷 村一太閤検地の村々を考えてみようと思うのである. 村落構造とはこの場合，特定経済構造の基盤の上に 成立する村落の政治的支配構造をいうのであるが， かかる村の構造とその形態とはもちろん直接的照応 関係にある。ここに村の形態を表象するるのとして 村境の問題が前面に浮び上つてこょう．村の構造や 村境論を地域的把握の原理において考究するのであ るが，そこには単なる自然的基礎の理解や復原の範 囲を越えて複杂化にからみ合う地域的諸条件との相関 を集中的に取り上げてみたいと思う。

\section{2. 「名的村」そその属人的村境}

検地帖より䆜われる「名的村」とは一体いかなる 性格をになつた村落であろうか.

池田

1 所

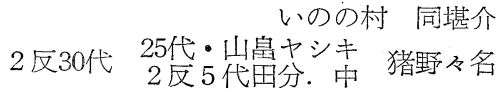
一以下同様式につき省略一 5 町 6 反 35 代

田 分 2 町 4 反 25 代 アレ1反 10 代
山皇ヤシキ 3 町 2 反 10 代 アレ 2 反 20 代 （天正16年菲生谷地檢帖） 右は上菲生川と櫝山川の合流点の北岸，河岸段丘上 に展開する「いのの村」であるが，ここでは「いの
の村」「いのの名」「いのの堪介」の村一名一名請人 が一貫化された古い伝統関係を検地施行期にまで指 摘されうるのである.こうした村こそ《 1 村 1 名 1 名請人》の村としての「名的村」の典型的な実例で ある.この場合では戦国期の「領主的名」の村が統 一政権出現のため変質し，私領主の村の否定の結果 かかる類型の封建村落に「村付」されるにいたつた のである、それにしても名主による在地支配の在来 的権威は強く存続する．名主対国主（長宗我部氏） の上部関係にこそ改変をうけながらも下部関係すな わち名主対冝接耕作者については古き在来的構造， つまり名主を頂点とする族因的共固体の村として存 したのである.このタイプの村落分布は第 1 図にし

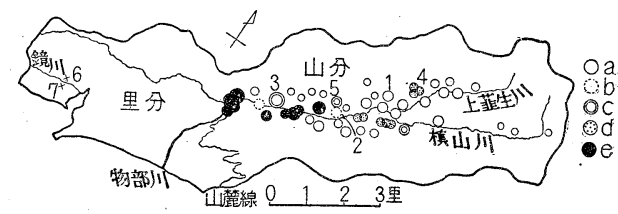

第 1 図 名的村の類型とその主要なる村落分布

1 , 猪野从村 2 , 永野八村 3 , 五百蔵〉村 4 , 上池八村

5 , 朴木八村 6 , 大高坂郷 7 , 潮江郷

$a, 1$ 村 1 名 1 名請人の村 b, 1 村 1 名小数名請人の村

c, 1 村少数名 1 名請人村村 $d, 1$ 村少数名請人の村

$\mathrm{e}$, 給人の村と名的村の中閖村

めす通りであるが，「名」分解速度の最ひ遅渧的な 奥菲生に分布の重心が認められる.

最も古い形をとどめる上述類型村についで「永野 ノ村」で代表される《1村 1 名少数名請人》の村が ある. 名内の地侍と加名主の血緑分家が一応外形的 には個別的な小経営の単位とはなつている.しかし これら新扣主の土地所有規模は零細でかつ「屋敷 持」でないのが普通であり名主に依存的であるのは いろんな22点より例証できる. 個別経営者といつて も名主に従属的な協在家的所在であるかぎり，この

1）松本豊寿；初期城下町の歴史地理学的研究. 1956.（自費出版）

2）松本豊寿；前揭書 212. 検地例を若干あげれば次のようである.
同ノ西
1 所
13 代
皇夕下
中西
36 代
下々
$\begin{array}{cc}\text { 永野ノ村 } & \text { 永野 } \\ \text { 同同 }\end{array}$
永野源兵卫扣
市ㅗ門扣
同扣
（天正16年菲生谷地検帖） 
型の村もやはり前にみた村との本質的な相異を認め がたい。ただ《1村 1 名 1 名請人》の村が変様の第 一歩をふみだしたものが本類型の村々といえよう。

本名主が隷属的な協名的小村を分出し，ないしは 強豪名が弱小名を合併して一個の村落を形成するの が 《 1 村少数名 1 名請人》の村なのである. 山田郷 内の有力地方領主であつた五百蔵氏によつて同氏の 本貫地「五百蔵分」の外に「中平分」その他を併せ 瞦張した「五百蔵ノ村」はがんらいはこのタイプの 村であつたと思われる．室町以来㯖山專当職を世襲 した槙山渓谷带の土豪守当代による「專当ノ村」も， 村付変更後は二名半の合併によつてこの類型の村に 成長する契機をもつ，この種の村々には相対的には 大村がみられ，前記「五百蔵ノ村」のごときは登録 耕地 18 町歩余に抢よんでいる.

物部川溪谷带で脇名が別個の経営体として特立し 本名へと成立した尋例を確認しうるに足る資料は未 だ接していない。しかし戦国の動乱期にあつてはこ うした動きが次第に激しくなつたであろう事は充分 に考えられるところである，なおまたいくつかの独 立した市小名が地域的に接近競合する場合，これら が一括して「村付」される例はけつしてすくなくは ないささらにまた新開村ならびに旧名主没落の村に 隣接する有力名主の進出の結果, 村落支配の入組関 係をみる場合がある. 第一の場合は鬼角として第二 のものでは「上池ノ村」「下池ノ村」「梶佐古ノ村」 があげられ，最後の事例と考えられるものに「塩ノ 村」「烯野ノ村」等がある。これらはいずれも《1村 少数名少数名請人》の村として「村付」されるが， この種の村は上うするに単数の「名的村」がいろん な条件下に拄いて合体した複合体の村落といえよう。

「名的村」も生産力の発展に伴、名分解の促進と ともに，村の構造は変容をうけざるを得ない，具体 的には古き「名的村」が封建的土地に成長した給人 群によつて構成される「給人の村」への転化傾斜す
る過程として現わされる.ここに「名的村」と後述 する「里方」の純粋なる「給人の村」との激移的な 類型村が成立する．第一表はこうした村の一例とし て山田鄉「朴木ノ村」の場合をしめしたものである。

第 1 表 朴木の村名請地表(ただし 1 部)

\begin{tabular}{|c|c|c|c|}
\hline 分 & 給 & 地 & 積 \\
\hline - 高垣 分 & 高垣源左工門給 & 6反 & 5 代 0 \\
\hline 平 分 & 有瀬彦太夫給 & & 7. 0 \\
\hline 有 光 分 & 永野源兵卫給 & 2 町 1. & 7. 0 \\
\hline 理清隠分 & 同上 上 & 2. & 33. 5 分 \\
\hline 代官 分 & 北村喜介給 & & 46. 2 \\
\hline 近 対 分 & 前 田千 鎘 給 & 8. & 0.0 \\
\hline 普 光 分 & 野中万千代給 & 1. & 0.0 \\
\hline 大西分 & 川 口給 & & 5. 0 \\
\hline - 前田 分 & 前田七又閒給 & & 15. 0 \\
\hline - 安丸名 & 主 扣 & & 16. 0 \\
\hline
\end{tabular}

(名請地表の全貌は抵稿“近世初頭の村落，その穙造と村境に ついて”を参照されたし）

・分の名前と給の名前の一致する例

この村では村内名主系給人に並んで隣接村の給人的 土地所有の入持関係がみられ。個有な「名的村」の 構造はそれだけ分解の進行をみる・たたこここで注意 したいのは「名」や「分」といつた戦国大名の領国 体制に普遍的な耕地所有単位が，この時代に入つて も依然として残存するのが第一点である.

第二点としては「名」や「分」と給地との特殊関 係である.

双方の間には一定の規範があり特定の「分」はか ならず特定の給人と結びつき他とはいずれも関係が ない。つまり「分」でみられる旧い村の分解を給人 名で知られる新らしい村の分解に置き換えうること。 換言すれば村は現実的に分解転質をうけながらもそ の分解速度がさまで大でなく分解の進行が多分に停 滞旧守的であるのを知りうるのである．本類型村の 多くは純粼な「給人の村」と山間部の「名的村」と の潮移地帯に分布の重心を認めうること，さらに山 閒地万でも生産力の高位な地域をしめる点が認めら れるが，かかる現象の綜体的な解明はいずれ後述す 
ることにしょう。

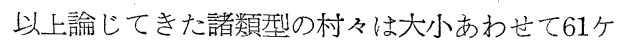
村，その $90 \%$ は耕地登録地積 10 町歩以内で抢しな べて小村であるのに気が付く. 次にこれらの村々で は「扣地名請」の形をとるものが多い，有力名主系 扣主はもとょり地侍としての秋持人であつても， 国主の給人団に編入されて身分的上昇をつかむ機会 にめぐまれなかつたわけである、それにして子給人 だあると扣主であるとを問わず名主二名本の伝統的 にして強力な在地支配の慣習的体制が存続していた のを知る.「名的村」のこの様な特色は中世以来の 歴史的結び付であるとともに，またそれは地域的表 現の特色として理解されうる，つまり村は「名主の 村」である限りこうした歴史的現実の中から「一円 の御名」としてのにらみのきく地域的䈇域の確認が 重視されざるを得ない，例の「四至堺注文案」が問 題となるのはこうした事情にもとずくものであるが， 以下村境論の立場において右の間題に若干の注解を 加えてみたい。

庄谷相根須の大境之事

1.ネコロカサアナノヨコ道クロ岩ヌタノホリキ リ一(以下四至記載省略) 一

御地給庄谷相门らかへ下りいろて根須庄谷相面々 談合あり申候分二月廿一日吉左卫門二的承候而如 比候 (天正 16 年菲生谷地検帖)

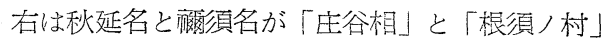
に村付される際. 村境が検地役人立会下において双 方の名主職所有者の談合による沠定，つ车り従来の 私的な名主による属人的支配の範域を梌地施行にさ いして公的なものとして再確認することによつて成

立したのを知る. 右は《 1 村 1 名 1 名請人》の村の 場合であるがその他でも『梖山大良兵工分卜永瀬卜 ノ大堺』のごとく，天正検地村の村境は極めて素朴 的に名主分境におきかえられているのをみる。《1 村少数名 1 名壸人》の村である「五百蔵/村」では 検村地記載の初めと終りに，『自是五百蔵権介方の 呼傍士』という名主方の呼僻示が詳記されている. 以上でよくわかる樣に「名的村」とは要するに実質 的にはあくまでも名主支配の村であり，中世的名共 同体遺制の極めて濃厚な村落といえる。こうした前 代的関係が長宗我部氏の統一政権下にあつてもなお 幽容認されたところに，山間溪谷带に展䦤された 「山分」村落の地域的特色が存するのである. とこ ろで 2 つ上の名主勢力の入組関係にある《1村少 数名少数名請人》の村ではどうであろうか。

同

1 所 1 反 20 代中

同南

1 所1反 下

同ノ南山ノ根

1 所 2 反 20 代中

同

1 所 40 代中大日修理田同上沲名分

一以下省略一（天正 16 年菲生谷舆 12 名地検帖）

右流「上池ノ村」の例であるが当村では寺領分を 除くとすべて「上池」「下池」「楃佐古」の隣接三名 主による錯熏的な名主的4)所有の大組関係が認めら れる、これはまさしくいわゆる『村㽖』以前の状態 を亘截的に表示するものであり，かかる現象こそ太 閤検地の村々の一般的特色といえる.したがつてこ

3）名主の扣主としての家臣団組入れを「蜜簡集」では「如望名之儀扶持」と呼んでいる。同じ国主の扶持 人でも給人＝地頭と扣主とでは経済的収取䦥係において大差があつた。

4）上池村の「分」別登録耕地は次の様である.

神通寺分 15 反 25 代 下池名分 2.20

上池名分 17.2 梶佐古名分 1.11 .4$. 
の場合には隣接村との村境記載は今までみてきた呼 傍示の形においては表出不可能といわざるまでもき わめて因難であり，現にこれと同じタイプに属する 村々にあつては村境記載がみられないのである。点 と点とを結ぶ名主支配域の執执とをで思われる呼傍 示記載の村々と，「上池ノ村」のごとくまつたくそ れを欠除する村々の姿は一見対立的とも考えられよ うが，「名的村」が奏質的には名主の村であるとい ろ本質よりみれば，実は1つの事実の翼つた形にお けるウラ八ラの関係をしめすにすぎないのである.

天正検地の物部川渓谷黄の村々が慶長以降の村の 記载とことなるところは「某ノ村」という所有格の 表示法である。「上池ノ村」「梶伿古ノ村」であつて 泆して「上池村」「梶佐古村」ではない。これらはけ だし天正の「名的村」の本質をよくついているとい える・村とは外なら㰠「名」を負う村，つまり名主 職所有者の村であるという事情が極めてよく具象化 されている・ところで名主支配の範国は既存耕地を こえて四囲の林野に伸長する。これらの林野は将来 耕地化の可能性を内含する.これらの林野は将来耕 地化の可能性を内含するとともに，山林資源定再生 産5)する場として名主的所有の切実なる照求の対象 とならざる走得ない。ともあれこうした名主のにら みのきく最外囲の地点を結んだものが「名的村」の 村境なのである・換言すれば伝統的な属人的支配に 實徹されたものが「名的村」の本然の姿といえる.

「名的村」は「太閤検地」の村々でもこの関係を最 もシンプルにしかもよく象微的に表現するものとい えよう.

\section{3.「給人の村」とその地象的柯境}

物部川流域孔下流地方，すなわち高知平野の「里 分」にあつては、今までみてきた「山分」の村々と

5）年号不明「清瓜分諸公事注文」（安芸文書）

6）《給付扣主》とは給人の土地領有下において扣主が土地所有権を容認される場合に生ずる直接耕作者の分 割的土地所有権をしめすものである。扣室の土地所有は給人的土地所有ないし領有といつた制限内に打い て発動するという限定性をもつ．検地記載例については註 7）を参照.
は村落共同体の構造的内容や形態において極めて対 蹠的性格がみとめられる. まずこの地域では村の概 念が検地施行後といえども不定であるのに気がつく。 検地施行の地域単元は庄郷という廃用機関化された 歴史的区域の上にのりかかつているが，これは明ら かに天正末期の歴史的現実とは適合しない。といつ て新らしい村落体系は制度的には確立されてはいず， 検地帖での柇の内容には自然村と行政村の概念が末 分離のままに混在する場合が多い。

「給人の村」の成立事情をあきらかにするにはこ の地域における名体制（地方領主体制を含めて）の 解体過程を明らかにしなければならないが，ここで はあえて省略しょう，ところで名解体に面面してそ の後にきたるべきものはなんであろらか。これこそ 「里分」地方に普遍的な給人的土地所有に基ずく 「給人の村」なのである。

これはもとより制度化されてはいない。しかし具 体的慣兒的事実としてはこの時点に厳存するものと して確認されていたのである．ともあれ村の主要地 域は大小様々の犬歯錯綜する給地に被われてほとん どあますところがない，独立小農民の成長む確かに 部分的には指摘されうるもの，その多くは給人的土 地所有に依存的な《給付扣主 ${ }^{6} 》 》 の$ 段觜に止まるも のである.

すくなくとも彼等は主体的な村の構成員ではあり えない.そのレギュラーメンバーはどこまでも給人 ＝地頭団であり，これら給人層は中世的な鄉支配者 に代る新興勢力を代表するものであつた．生産力の 高いこの地域では中小名主級の直接生産者といえど も地侍化し給人に上昇する可能性をむつていた＼cjkstart高 知平野によくみられる「給」「扣」「作」の複雑なる 重層的名請組合せは，こうした新興階層の上級階層 
に対する得分の獲得への努力の跡を物語るものとい えようとくに戦国期における地方領主閒の軍事的 対立は戦斗力拡充の必要上り有力農民をも武装兵団 讹する契機を与えたのである。さらに城下町を中心 とする領主手工業の発達は「鍛冶」「番匠」等の特 晒職給人が蚎」「定尺」等の武家奉公人の給人と ならんで輩出する傾向を強めた。こうした給人層は 地方領主系の上級給人＝「城持」に対し下級給人団 を形成するものであるが，これら給人の慗的結合に は相異なる結合要素を混在せしめているのに注意し たい。第 1 は上級下級の両給人団の間において形成 された兵団統制上の「寄親寄子」の同心組織であり， 他は在地の一般給人が「1町臯」「2町衆」等とい われる様に現实的には農民的給人としての事実の上 にたつ惣村的結合である．前者は村落を越えた対人 的結合であるが，後者は明らかに直接耕作者として の立場におけるる地域的結合である。この地域的結合 は「吉原衆」「甘枝衆」「大高坂紊」等の郷村名を負 う衆名 ${ }^{8)}$ によつて䝷い得るものであるが，「給人の 村」の地域的結合の実態は実にこの検地帖記載の寀 名分析によつて相当程度に復原しうるのである.

さてこの場合まず問題にしたいのは給人団の横へ の結合にみられる地域そのものが，伝統的なそして 検地施行の地域単元となつた旧庄郷としばしば一致 しない場合に遭遇することである中世の「名」を 地域蕁成の細胞としその上に形成された庄郷と，と もかくも新らしい歴史的環境的条件下より生れでた 「給人の村」の地域単位との間にこうした飧違い

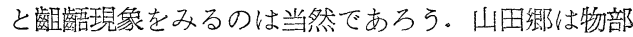
扇状地とその背後の溪谷帯を包括する広い拡がりを もつていたが，それが今や「山田菜」「菲生衆」の 衆名が物語る様に「山分」と「里分」に分立するの である，その境界が丁度，「給人の村」と「名的村」 の境界と一致するのはけだし偶然ではなかろう。同 様な事例は他にもすくなくはなく大忍庄や蔂深淵楖, さらに江村郷等をあげることができる。いずれにし ても庄郷より分立した枝村の新「給人の村」は，旧 生郷とは村の構造において明らかに買質的垉域とな つている．市場集落の旧庄郷よりの自立化は顕著な 事実であり，農村閒の分立現象より先行して行われ た形跡がある・たとへば「大高坂新市」は検地帖て は大高坂郷の中に包含されてはいるが，「市中」「町 衆」の用語がしめす様に別個の異つた集落体であり， かつ「目代」「月泰」による独自の惣的自治組織を もつていた，都市的集落の農村よりの分化は，自然 発生的なものというよりは新領国体制をうちたてる ための国主による重要なる政策的表現である点につ いてはすでに8論じてきた通りである.この様な 「給人の村」の旧庄郷よりの分立と細分化にはいろ んな条件が作用しているが，とくにここでは村構成 員が上級得分者である代官的名主より現実耕作者の 要素を加へ来つた名主百姓といつた様に、生産の社 会的単元が大家族より小家族に移行するにつれて惣 共同体範域の縮少10)をみるのが原則であるのに注意 したい。その最終的な地域的村落的表象が外ならぬ 本百姓を基盤とする藩政村の村々といえよう。

7) 同じの下谷ソへ

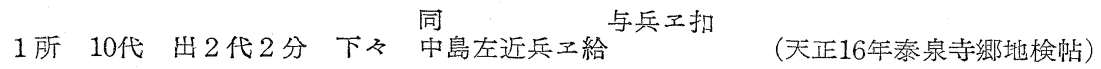

8）同八西福田村

1 所 20 代 出28代中ャシキ山田衆 福田島门口給

立田境 包地村

1 所 32 代 出 5 代上ヤジキ大津衆 野中喜七給 （天正16年岩村郷地検帖）

9）松本豊寿；中世より近世過渡期における地方市場集落，その形成と存在形態並に变質について．社会経 済史学. 22, 4, 80.

10）「給人の村」に抢ける旧庄郷の細分化は後期的形成による寄進地系庄園に著しい。ここで庄域の拡大 が在地構造と無関你に進行するのであつて，その好例として大忍庄をあげることができる. 
それにしてし旧庄郷と「給人の村」が地域的に一 致する場合も決してすくなくはない，野田村＝野田 衆 一宮庄 $=$ 一宮衆 大津郷=大津采 秦泉寺郷 $=$ 秦泉寺衆等々といつた具合である.これらは検地帖 の形式からいえば「 1 村 1 検地帖」の村々であるが， こうした村々には村域並に村成立の立地条件におい て共通的な要素が存在する.村域については「里分」 の村々としては相対的に狭少でほぼ百町歩前後の相 似た地域的拡りをもつ，その多くは山麓線上に立地 し1種の自然地理学的単元をなすがゆえに地域的に 早くょり固定する様になつたと思われる. その地域 範囲はかつての小領主による土豪的支配領域とも一 致し「「野田」「秦泉寺」「池」等はまたそのまま土 豪名でもある，この狭い地域的完結性は名主連合の 庄郷的地域単位としてもまた給人のそれにも適合す るのみならず，その多くはそのままに藩政村の村へ と移行している．すでに別稿で論じた様に給人の農 業経営者としての在り方には，中世の名主百姓と近 世の屋敷持本百姓とを連結する側面をもつている. つまり天正期給人の農民的側面には，かつての当名 主的性格と初期本百姓的性質がそのものの中にだき 合せになつているわけである・「給人の村」が旧庄 郷と時としては敬龆しまた 1 万との村落立地条件に よつては逆に一致するという一見背反的ともみられ る現象も，村棈成員である給人が基本的には中世と 近世を連結する漸移中閒的存在である事実を再認す るとき，しかく単純に矛盾現象として律し去るべき ものではなかろう。

以上みてきた様に「給人の村」の成熟にともなつ て新村落の地域概念が次第にハッキリと事実上固定 化されてくる以上，封建支配としては何等かの行政 的対応策をうちたてざるを得なくなる，それはよう するに旧庄郷的在所制度の根本的な克服否定と，行 政村としての近世的村落樹立への育成努力の過程と
なつて現われてくる．ここに「百ケ条」や「代官戍 屋刀弥帖」にしめされる慶長二年の村落制度のもつ 重要性が存するのである. 慶長に入るとこの地方な りでの近世化の傾斜のゆえに村の構造は破かに一歩 前進した・長宗我部政権もこの段階になると直接耕 作者を給人的支配よりきりはなし，その中間的支配 を制限ないしは停止せんとする動ぎがしだいに正 常化されてゆく，具体的には官選の「庄屋」「刀弥」 を任命し在所百姓を直接国主配下に定置する事であ るが，それが在所制度として結晶したものが行政村 としての慶長初頭の村々なのである。つまり「給人 の村」の中より疑もなく異質的な「百姓＝《自営的 扣主》の村」の創設となつて現われてくる.

しかしここに問題がある.この地方では給人＝地 頭の城下町への集中は進捗せず彼等は最後まで農業 より分離することがなかつた したがつて白ケ 条」に『其在所為地頭庄屋近所のもの』と表現され ている様に，村はやはり「給人の村」としての性格 が沠して払拭されてはいないのである。慶長の村は 「給人の村」であると同時に「百﨡の村」であり峏 者が複合的に並存して一種の二重構造をみせるとい えよう．村構成員は百姓に対する庄屋刀弥，一般給 人に対する「代官」もしくば「人数預」(いずれも上 級給人）という別個の媒介者をむつて統一政権と結 びついているのである。

$$
\begin{aligned}
& \text { 大高坂〈人数預 吉田次郎左卫聞 } \\
& \text { 庄 屋 } 4 \text { 反 } 1 \text { 代窝田源兵工 } \\
& 5 \text { 反 } 31 \text { 代室彦四郎 } \\
& \text { 永 浜〈代 官 } 5 \text { 反 } 39 \text { 代獚山九郎兵卫 }
\end{aligned}
$$

右の事列がよく物語る様に給人人口の多い高知平 野では代官庄屋による二重支配の構造が極めて具象 的に表現されている．ともあれ慶長の村では「給人 の村」の連続面としての古さと，それをつきやふりり 揚革せんとする新らしさが末分離のままに矛盾的に

11)「国中諸百姓地頭庄屋為奉公人随分あひはぐくむへし若相定成物以外りんじの用所不可申懸事」(百ヶ条) 
並立しているが，その制度的表現が過湾的な双分支 配の二重構造の村に外ならないのである，專害慶長 の村ではその形態面，たとえば村落区劃や村分立等 の問題を取り上げるならば全く「給人の村」の段階 をさまで克服するものではないこの点に関する詳 細なる解眀については別稿を参照されれば幸である。

「名的村」ではその村境とは要するに旧名主勢力 による属人的境界であつた.これに対し「給人の村」 はかかる「名」の解体の上に樹立されたものである 以上，村境の概念と内容は相当に異つたものとして 現われざるを得ない。

(その I )

東八鏡郡上它分是ヨリ西八長岡郡政居田村 (妙? )

傍止门円挲寺鎮守ノ社境ナリ

（天正 16 年長岡郡嗐居田村地検帖）

(その II)
キテウ满力ケテ前地 2 反岩村堺 小島分
1所 1 区 46 代 3 分 下時入 中内菊給
同ノ西满力ケテ岩村堺前地 1 反
1所 47 代下同门

キテウ溝カケテ岩村堺

1所 4反20代 芐19代同 门左兵衛給 （天正 16 年香美郡山田郷地検帖）

右は高知平野における代表的な傍示表示の 2 列で ある、第 1 の資料は「上庄分」といつた旧圷境がそ のまま「給人の村」の境界に適用されている例であ り，第 IIは名請地が 1 反またはその整数倍となつて いる一事だけでも知られる様に，ここでは旧条里境 界を村境に踏襲した事例である。さて中小規模の農 民的給人による地域的結合単位が結局「給人の村」 に外ならないのであるが，その共同体規模には平均 的な限界があり，この地方ではすでに言及したよう に集村で耕地登録 10し町前後のところにほぼ基準が おかれうる様である.

ところでこうした「給人の村」の内部は個別的経 営を軸とする多数の給人による村構成員の営農事実 に基ずく生活空間が展開し，それらは直接に相互接
触しっないしは競合するゆえにこの地方での村境と は名的村のごとき点と点を薑初る不定的境界ではな く線と線をつなぐ固定的境界が要求されざるを得な い. 固定的境界は線状境界の形をとるゆえにこの場 合では条里とか旧庄境等の廃用機関化した歴史的境 界の一部が，「繩手限り」「溝限り」等といつた顕著 な地形線と共に，村と村，集落と集落を劃する村境 として現夷的な意義を復活するのである：この様な 現象を招来した所以のものは属人的境界の否定の中 加具象的な属地的境界を要望する給人的農民によ る封建村落成熟の基盤より必然的に導かれる性質の ものといえる・それにしてもかつての地方領主が归 領主体制こそ分解をうけながらを，上級給人として 在地に健在している場合はどうであろうか。鏡川を はさんで南北に対立する 2 つの拫村，国沢殿のよる 大高坂鄉と森殿の本拋潮江郷の場合について，1，2 考えてみたいと思う。

コクテウ 大高坂村

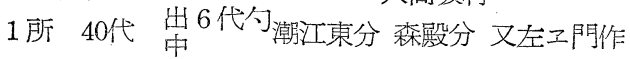
1 上キレ 14 代 4 分 中 同 東分 同じ分 新卫門作 同ノ北前地 30 代

1 所 25 代 中 同西分 彦九郎名

同八北前地 30 代同

1 所 24 代上同 西分 楠瀬与三左卫門給 一省略一（天正 16 年大高坂郷地検帖）

同東川フチ潮江村国沢分

1 所 1 反 20 代 2 分 中 御公領 徳久五郎兵卫給 同東東地ノカカリ同同 分

1所 20 代 下 橋瓜七郎工門給

同ノ北

1 所 1 区 20 代中德久角介給

同ノ東東地ノカカリ 1 所 8 代门 一省略一

同同分 アレ 千穎八郎卫門給
（天正16年川原ヨリ南地検帖）

大高坂郷南辺の「潮江分」と潮江郷北辺の「国沢 分」との団塊的な対立的所在は，これだけのことで 考えるならば先に述べた「名的村」の「上池ノ村」 と一応同樣なる現象とうけとられるかもしれない。 しかし次の事実による両者の本質的相異に改めて注 
意を払う必要がある.

まずこの場合の「分」は「名的村」の「分」とは全 然性質の異なるのに気付くのであろう.つまり両郷 での「分」は潮江分＝森殿，国沢分＝国沢殿という属 人的一円支配の所領を意味するのではない・今，潮 江郷「国沢分」をみるとその一部は公領化され，さら に他の 2 町歩前後の名請地もその一円支配は分解を うけ 18 人の給人団による錯國的所有に帰している のである、同様なる事情は「潮江西分」でもいえる。 強いて例外を挙げれば「潮江東分」で寺領以外は森 殿所領となり他の進出をはばんでいる。もつともこ れとても「潮江分」が 2 分されかつ森殿の本貫地潮 江郷ではハッキリと「不分」の百姓扣地が分出して いる現象をみるときここにも我々は進行している 領主体制の崩壊過程をまざまざとみせつけられるで あろう. 要するにここでの「分」はかつての私領主 の村の段階においては「名的村」の村境分にも似た 状態を経由したであろう歴史性をこそ示しはこそす れ，検地施行の時点においては領主的所領の「分」 の性質は一路解体分裂の途をたどつているのである.

大高坂之御城迴，東八海詰テ西八新市西鹿穴限 南八潮江之川限，北八大川ヨ詰テ中ノ帖也

（天正 16 年大高坂地検帖） 右の傍示は大高坂の城下町建設にともなう新城下 都市域の境域を確定したものである，自然境界を外 毭線とて利用しているのは極くありふれた現象であ るが，境域が旧い属人的境界を寸断している事実に 注意支払いたい，新境界は旧領主村の名残である 「森分」「国沢分」の「分」地とは無関係にそれらを 分断して特設されたのみならず，城下都市域という 特殊性は給地入替と公領化を押し進めているのを知 る. 境界をはさんで入組む「分」地所在は，むしも 『村切』が行われるなればそのまま藩政村の飛地と
なろう. かつての雇人的境界は今や明白に地縁的境 界に取つて替わられたのである。

\section{4. 村落型のパターンを規定する条件}

「名的村」の地域境界と「給人の村」のそれを線 区分法で表示すること自体はあまり大した意義をむ つものではない。ただ次の現象すなわち，上述の 2 類型村の発達は物部川の谷口附近を漸移地带として 上流と下流部に展開する対蹠的分布事奏を確認すれ ばたりよう、つまり物部渓谷帯に対する高知严野,

「山分」に対する「里分」の双分的発達がみられる のである. かかる分布の特性を規定する地域自体の 内在的条件として，䇥者は 1 つに土地生産力とい つた自然性，2つには水田農業と畑作，それもとく に焼畑耕作を中心とした営農型態の地域差を考えて みたいと思う。

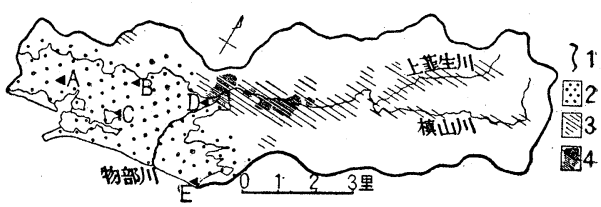

第 2 図名的村と給人ノ村の対踫的分布 1. 山管線 2. 給人ノ村 3. 名的村 4. 中間類型村 A. 大高坂城下町 B. 剛䁗城 C. 大津城 D. 山田城, E. 姫倉城

まず土地生産力であるが，これには上田率を取り 上げてみた・課税率が一般に土地肥沃度に対応する ものである以上，田品規定には強い領主的関心が払

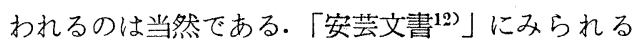
様な各生鄉個有の中世的田品規定も統一政権の確立 に伴い整理調製されて天正検地では「上」「中」「下」 「下々」の四分制に統一される，上田率とは要する に単位地積に対する上田地積の比であるが，巨視的 には大体において耕地の自然性を具象しているとみ て差支えなかろう.

この分布圈で容易に気付く点は，上田率圈が全く

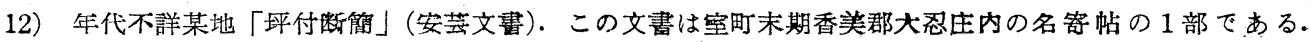
「上々」「上」の田品がしめされている. 


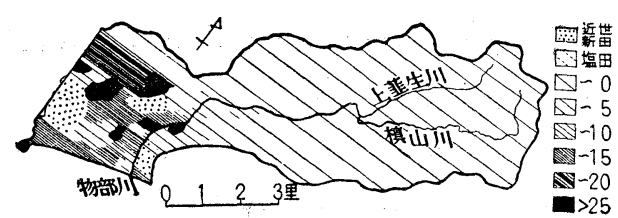

第 3 図天正検地による物部川流域の上田率図 村落型分布圈と照合する現象であろう。同じ溪谷带 でも高位生産力地域にあつてはすでにみた様にまた ことなつた亜類型村の発達を確認しうるのである。 一定度以上の土地生産力が欠ける場合においては， 直接生産者の社会的成長，村落社会構成の新らしい 進展はむつかしいかまたは遅滞する，低位生産力の 地域にあつては，耕作農民が自給生産以外の余剩生 産を確保して封建的土地所有者の重圧より抜け出し てくる自然的経済基盤に欠けるのであるたかだか 名主職所有者に依存する少数の小経営単位が新「扣 主」として登録されるに止まり，隷農の自立と分出 上昇は極めて強い制約をうける・したがつて村の構 造は変化しにくく旧守性と停滞性が村々を被うにい たる.山間溪谷帯に特色的な「名的村」の優位と卓 越は，まさしくこの椂な規定的理由より生れいでた むのと思われる. 一方「里分」ではどうであろうか.
ここでは旧領主的，ないしは名主的所有に対する直 接耕作者のつきあげが特色的である，その具体的現 われが中小扣主の給人化と特殊職庶民の下級給人化 への途であつた・ともあれこうした一連の地域的現 象を可能にした基本的条件はなんといつても余剩生 産を許容する土地生産力の高さに起因し，その直截 的な現われが前述した名請組合せの特質=「給」「扣」 「作」の重層的組合せに外ならない。もしもそうで なかつたならば，重層的名請関係より招来する細分 化された得分の分け合いは第一不可能となるのでは なかろらか。

土地生産力の場所的相異の上に匡開された生産関 係を，特定の視点から整理すれば営農形態の地域的 相異としてうけとめることができる。ここに水田農 業と畑作農業の問題が表面にでてくる．封建制下の 農業が年貢地耕作の基軸の上に展開し水田則農業の 基本的な考え万の上にうちたてられたものである以 上，耕地の水田化とその維持は凡ゆる困難を排して 強行されたものであつた. 今，天正検地の高知平野 から $2 ， 3$ の鄉村を抽出し田畑地積を比較してみよ う. 右表の中，山田鄉は平野村といつても開析のす すんた段丘上に成立する村（現山田町片 地）であるが畑作経営は予想外にすくな い.ともあれ右表より「里分」地方はお。 しなべて皆田地域といつても大過ないの である。

ところで渓谷帯に入ると畑作率は確実 に增加をきたし，上流渓谷带である奥菲 生，槙山に至ればそれはついに決定的と なる，右表はそれでもまだまだ畑作経営 の本然の姿を顕現したものとはいえない， 実はこの外に広大なる地積に亘る切畑経 営がかくされているのである.ことわる までもなく切畑経営は，自然経済的な農 民生活の再生産のためには極めて重要な 
る意義をもつ. 天正 16 年の「先の検地」より僅か に 3 年を距てた同 19 年に再検地が溪谷带の一部に 施行されたのはすこぶる興味が深い。ここでは新ら しく切畑が登録され，しかもその高 ${ }^{13)}$ はほぼ本田総 地積に匹敵する. 従来は自給生産の補助手段として 黙認された「高の外」なる広大な切畑が，領主的支 配の対象として急速かつ強力に組入れられてゆくと ころに，この特異な農業経営のさつ重要性が改めて 認識されるのであろう。

この様な「山分」の村々での畑作並に切畑経営の 優位性は村々の類型形成に基本的な規定関係をもつ。 まず畑作経営は閉された地域社会の個別的発達を助 長する要素をになつているのにたいし，灌溉農業と しての水田経営には対立的な別個の性格を具有する ものである．灌溉農業は用排水路の共同管理を通じ て村と村，生郷と生鄉とを結ふ地域的連合，つまり 広域なる「組村」の成立をもたらす契機となる事は 従来よりよくいわれてきた通りである。しかし一方 畑作農業ではその粗放的経営や農業労働力が単婚家 族を基軸とする等々のゆえに，地域連带的な生産地 ユニットの背景をさまで必要とはしないのである. 水田農業では隣接地刺激と地域的同質化が強く作用 するに対し，畑作農業ではなんといつてもそれは弱 体化されて現われざるを得ない，村の類型が水田農 業を主体とする平野村では容易に類同化される要素 をもつのに対して，烟作農業を主軸とする山間村で はその現われは遅滞化する．旧守的，後進的な村々 の姿を外围的環境からつきくずす生産関倸展開の必 然性が，このままの営農状態では現実的に稀薄化さ れざるを得ないのである.

次に切畑経営のもつ村落構造に対する規制作用が

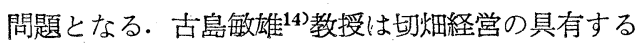

特質として火入れと獣害の団体的防筫を通してて畑作 一般には欠けている共同体的色彩を強調しているが， それは特に封建村落の場合により強力に作用する事 を指摘している，つまりこの場合には村々を越えて の遠心的な共同体的結びつきではなく，逆に村自体 の求心的，完結的な共同体的強制力が強力に作用す るわけである. 五王堂名の分析においてすでに論じ た様に，切畑登録人は名主二名本で代表される特定 層であつたすなわち本田での有力扣主にして初め て切畑名請人たりうるのである. 被官層の生活農業 の中心が切畑におかれるとはよくいわれるところで ある.しかし当初における切畑開発には本田で蓄積 された一定度以上の営農力か強い前提となるもので ありっとくにそれは切畑経営のもつ共同体的強制力 のゆえにますます濃化の傾向をたどる，以上の様な 切畑農業の特性は必然の結果として農民層の分化を 遅漁せしめ，䍮農の自立化を阻害する条件としては たらく，村々をして新らしい封建村落化へとつきあ げうる力の欠除が認められる.したがつて山間の 「名的村」といつた古い様相のきりくずしは新生産 様式導入等の環境的条件の転化がないかぎり仲及容 易には進行しない，村の構造の転質と前進は緩慢に しか進行しないのである.こここに最も典型的な「名 的村」の出現する地域と切畑農業の優位する地域の 一致現象が，決して偶然であり得ない理由もまた自 ずと明らかとなろう。

5. あとがき＝異質的村落の地域的時間的統一関 係を中心に=

2 つの異質的な村類型の同時的並存，即ち「名的 村」と「給人の村」との間にははなしてどの様な相 互関連性があり，かつそれが時の経過と共にどの様 な一体化への道をたどつたのであろうか．長宗我部

13）例を「五王堂/村」にとれば，前検地の本高 6 町 6 反 38 代に対し，切畑は 5 町 25 代に及ぶ.これと相 似た数字は「清瓜ノ村」でも認めることができる.

14）古島敏雄 (1943)；近世日本農業の構造. 288 . 
政権下にあつては,「給人の村」が封建村落として の主体をなしていた事実については筳をさしはさむ 余地がない.領主権力の基盤は「給人の村」を細胞 とすする領国構造の中につちかわれていたものであつ た：生園体制の克服と揚棄を意図する統一政権の立 場にあつては，もとより「名的村」は可能なる限り 「給人の村」へと転質させたいのであつたがすでに みた様な在地構造の特殊性のゆえに古い形䯟の存続 を許容し，これと妥協せざるを得なかつたのである。 $2 つ の$ 村類型の対立は一見たしかに1つの渠溝とし てうつるのであろう. しかし在地の自然性や社会構 造のあり方がこの様な形と段階差をとること自体は， あくまで必然性をもつている.

こうした必然性の基体の上にたつて，「給人の村」 を主軸とし「名的村」を副次的残存体として、両者 は領主権力のもとに綜一的に把握されているわけで

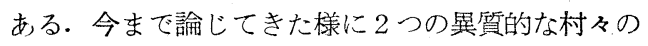
パターンには，確かに合法則性があり，かかるゆえ にこそそれはまたそれなりに1つの地理的な地域統 一体を形成する. 旧山田郷は分解しても本郷である 「山田」とその枝郷としての「菲生」は，相補的関 係において一体化し共存するのである。

天正期における異質的な村類型の同時的併存は幕 藩体制期に入るにつれて次第に異質的要素を整理淘 汰し同質的な村形成へと指向してゆくが，そのゆき つくところのものこそほかなら呠百姓の村」な のである。

慶長 2 年の村々はこの様な移行途上における $1 つ$ の過渡的漸移の姿を露呈する，ものであつた。ここで はかつての「給人の村」は本来的な「給人の村」と 「百姓二自営的扣主の村」との二重構造の村となつ ているが，この時点にあつて「山分」の「名的村」 に右と同様なるケースを望むのはもとより不可能て
ある・具体的には耕作農民自立化の未ださ，名主に 代る新興階層の未成熟は，隷農一旧名主一生屋の重 層的支配体制を招来した，耕作農民の間接的把握は その環境的条件と相まつて庄屋支配域をより広域 ${ }^{15)}$ 化するものであるが，「山分」でも例の中間類型村 卓越地域にあつては，相対的に小域の新分立 ${ }^{16)}$ 村を みるのはけだし興味深い現象といえよう。ともあれ 慶長での「里分」の村々は藩政村の直接的祖形であ つたが，「山分」の村々ではこれが元禄の近世村に まで到逹するまでにはもう一段の分化と再碸を必要 とするのである.

長宗我部氏より山内氏への政権交替は剓的共同体 の村より近世的共同体の村への変質に大きな意義を もつものであつたこの変動期は兵農分離の進行と ともに在地における旧勢力の没落，隷農の解放を促 進する契機となつて，かくて「給人の村」や「名的 村」は近世村への一歩を大きくふみだしたのであつ たが，この動向は筧文期を 1 つの境としてやがて 『元禄国郡帖』にしめされる最終的な段階二「本百 姓の村」に到達する．藩政期以降における近世的村 落への完全転質の具体的分析，しかもそれを歴史地 理学的にいかに把握するかの究明はまだまだ今後に 残された大きな課題といえよう.

二追記 $=$

本稿では歴史地理学としての理論構成の過程に 招けるその素材的解明つまり事象そのもの，歷 史学的説明についてはあえて最少限度に止めた。 ついてはその点の究明老目標としてかなりの詳 論を加えた『社会経济史学』への筆者の投稿論 文「近世初頭の村落その構造と村境について」 と併せ参照されれば幸である.

(1958年 5 月 27 日受理)

15）植山，菲生奥の 2 区分制となる。この地域範围は藩政期の大庄屋支配区域にほぼ一致する.

16）「菲生口分」「韮生小川」「西俣川之尾」の小村で代表される. 


\section{A HISTORICO-GEOGRAPHICAL RESEARCH ON THE VILLAGES IN THE EARLY MODERN AGE, THE MATERIALS TAKEN FROM “CHŌSOKABE KENCHICHŌ”. \\ Toyotoshi MATUMOTO}

The purpose of this research is to explain the structure and boundary of villages in the early part of modern age. The materials are taken from “Chōsokabe Kenchichō” (長宗我部檢地帖). In the structure the villages in the Monobe valley zone are in striking contrast to those of Kōchi plain. The writer thinks the villages in the valley zone are "Myōteki mura" (名的村) (villages like“"Myō") and those of the plain, villages of "Kyūjin" (給人).

Villages like, "Myō" have many characteristics of medieval "Myō" system. Villages of "Kyūjin" which are governed by "Kyūjin" came after villages like "Myō" which are governed by "Myōshu" (名主). "Kyũjin" is a "Bushi" (warrior) and farmar. In reality "Myōteki mura" is a village of "Myōshu", while a village of "Kyūjin" is a community made up of a number of independent farmers.

Accordingly, the boundary of "Myottekimura" is settled by the strength of the governor, while that of a villages of "Kyūjin" is settled by land.

The writer notices the two factors that caused this social phenomenon. One is productive power of land, and the other is method of farming.

It was due to these two factors that the above-mentioned two kinds of villages came into being.

\section{杤木県篣川橋梁付近の局地的強風についで}

\section{吉 野 正 敏}

\section{1. まえがき}

杤木県の那須扇状地を流れる篣川を，東北本線が 横切る橋梁付近（第 1 図）は，局地的に極めて強い 風が吹く・これまでにも，川すじに沿つて風が吹き やすいことはよく知られており, 関東平野の多数地 点におけるウインドローズ1をみても，河川の流路 に沿う風向の頻度が，河川の近くの地点においては 卓越している。しかし，その理由は，まだ常識的な 解釈しかされておらず，とくに捧しく調査されたこ ともないようである.

ところが，この問題の橋梁付近は，このような一 般的な川すじにおける強風以上に特別強いらしく，
これまで現地ではいろいろの被害が起つている。た とえば，橋梁上における強風による列車事故は過去 2 回記録されて抢り，その第 1 回は，明治 32 年 10 月 7 日 16 時に下り列車の客車 8 両・貨車 10 両・機 関車 2 両の全部が河中に転落し，死者 86 名を数え る大きいものであつた。このときの現場における風 は，宇都宮・水户両測候所の記録から推定すると， 風向はNWで，瞬間最大風速は $27 \sim 28 \mathrm{~m} / \mathrm{s}$ であつ たと考えられている2゙. 第 2 回目は昭和 25 年 1 月 10 日 23 時 26 分, 下り貨物列車の最後部緩急車ワフ 21371 が脱線した.このときの風向はNWで，野崎 駅における推定風速は 17-20時が $20 \sim 25 \mathrm{~m} / \mathrm{s} ， 20$

* 日本地理学会 1958 年春季大会にて発表.

1）畠山久尚 (1950)：関東地方における局地風の分布. 研究時報. 1 (特別号)，1-65

2）中央気象台測候課（1951？）：風害による列車脱線事故と当時の気象状況䅕查.（プッント）1-23 